\title{
18. NONCALCAREOUS PELAGIC SEDIMENTS FROM THE WESTERN PACIFIC: LEG 7, DEEP SEA DRILLING PROJECT
}

\author{
G. Ross Heath, Department of Oceanography, Oregon State University, Corvallis, Oregon, \\ and \\ Ralph Moberly, Jr., Hawaii Institute of Geophysics, University of Hawaii, Honolulu, Hawaii
}

\begin{abstract}
Noncalcareous pelagic deposits were sampled at four of the Leg 7 sites $(61,65,66,67)$. The Central Basin holes (65 and 66 ) each passed through more than 100 meters of very pure Tertiary siliceous ooze, indicating that neither the depth relative to the calcite compensation level nor the geographic position relative to the equatorial zone of high biological productivity has varied much since the Middle Eocene at these sites.
\end{abstract}

At site 66 , the siliceous ooze is underlain by very fine-grained pelagic clay. This deposit spans the Cretaceous-Tertiary boundary. It contains angular quartz shards and illite, suggestive of continental origin, as well as montmorillonite, attapulgite, anorthoclase and earthy ferromanganese oxides, suggestive of mid-ocean ridge volcanism and associated hydrothermal activity. Both the siliceous ooze and pelagic clay contain ferromanganese concretions, implying that they have been oxidized since they were deposited.

\section{SILICEOUS OOZES}

Opaline remains of radiolarians, and to a lesser extent diatoms, are present at all the sites drilled. However, only in the noncalcareous sections (Sites 61, 65, 66 and 67) do they become concentrated enough to form siliceous oozes. The coring programs at Sites 61 and 67 failed to sample the oozes, although they could be identified in cavings and deduced from the behavior of the drill.

At Sites 65 and 66, in the Central Basin, the shallowest lithological unit is a remarkably pure siliceous ooze which corresponds to an acoustically transparent layer on the reflection seismic (airgun) records. At Site 65, this unit, which is 123 meters thick, grades down to interbedded calcareous and siliceous oozes, and finally to interbedded porcelanites, silicified turbidites and siliceous ooze. The silica-rich section terminates at 168 meters where it is underlain by brown zeolitic pelagic clay. At Site 66, the siliceous ooze is about 148 meters thick (the interval from 126 to 148 meters was not sampled) and again grades into interbedded siliceous ooze (inferred from its drilling characteristics) and cherts before terminating on stiff pelagic clay at about 162 meters.

At both sites, the siliceous material is dominated by radiolarian tests. Diatom frustules are generally rare at
Site 65 , but range from common to abundant at Site 66 , which is closer to the equatorial zone of high biological productivity. Sponge spicules and silicoflagellate skeletons are present in most samples, but constitute a trivial proportion of the total silica. The Tertiary section includes the purest siliceous sediments (up to 98 per cent opal by visual estimate) at both sites. The Quaternary deposits of the Central Basin are richer in clay and silt than the older sediments, presumably as a result of the eolian introduction of continental debris generated by Pleistocene glaciation (Rex, 1958, Heath, 1969b).

The occurrence of the siliceous oozes at Sites 61 and 67, which lie north of the zone of modern biogenous sediments, implies that during the Paleogene, at least, conditions favored the preservation of opal over a much wider area than at present. Even allowing for the migration of the sea floor required by the new global tectonics, it is apparent that early and middle Tertiary siliceous oozes cover a much greater area than comparable Quaternary deposits. The accumulation rates derived from the biostratigraphic zonation of Sites 65 and 66 suggest that early and middle Tertiary siliceous deposits accumulated no faster than younger oozes. Thus, the extensive distribution of the older deposits implies better preservation of silica (i.e., less aggressive bottom water) rather than greater productivity. Such conditions 
could have arisen from a broadened equatorial zone of high productivity and sluggish deep circulation. Alternatively, a shift of the locus of silica deposition from high to low latitudes prior to the development of polar ice caps and large latitudinal thermal gradients during the late Tertiary could have produced the extensive deposits of Tertiary siliceous sediments of the equatorial areas, without requiring any change in the global budget of silica. Quaternary siliceous oozes in equatorial areas are found only below the calcite compensation depth. It is not altogether clear whether the occurrence of older siliceous oozes implies the same relationship, or whether siliceous and calcareous organisms were concentrated in different portions of the equatorial current system. There is some indication from the geographic distribution of siliceous and calcareous oozes that the siliceous organisms preferred the northern edge of the productive zone, while the calcareous organisms were more abundant at the center. However, the occurrence of calcareous intervals at Sites 65 and 66 suggest that the calcite compensation depth has influenced the distribution of equatorial biogenous oozes throughout the Tertiary. Work on sections cored during Legs 8 and 9 of the Deep Sea Drilling Project should help resolve the factors controlling the distribution of the two major types of biogenous sediment.

The siliceous deposits consist entirely of opal (hydrated silica with the structure of extremely fine-grained cristobalite). A few skeletons from early Tertiary samples show slight birefringence under crossed Nicols, but the absence of a corresponding change in the X-ray diffraction patterns of such samples suggests that the birefringence reflects strain (perhaps resulting from partial dehydration) rather than recrystallization. Even the Cretaceous Radiolaria from Site 61 still consist of opal.

The only mineralogical parameter of the siliceous deposits observed to correlate with age is the size normal to 101 of cristobalite crystallites. This size increases from about $11 \AA$ in Quaternary opal to about $15 \AA$ in Middle Eocene samples. Further work is required to determine whether the increase reflects partial dehydration, or simply a rearrangement of silicates $\left(\mathrm{SiO}_{4}\right.$ tetrahedra). Previous work on thermal inversion of opal to well-crystallized cristobalite (Heath 1968) and on the resistance of deep-sea opal to dissolution (Moore 1969) has indicated that, whatever its nature, the aging process makes the opal less reactive, and probably explains why reworked early Tertiary siliceous microfossils persist in Recent sediments from which all Quaternary species are being dissolved.

Because opal is much more soluble than crystalline forms of silica (Krauskopf, 1959), it is the most probable source of the silica forming the cherts encountered at all Leg 7 sites.
As discussed in the chapter on the Leg 7 cherts, the cherts consist largely of cristobalite and quartz. Although this cristobalite is finely crystalline ${ }_{8}$ its particle size normal to 101 is always greater than $45 \AA$. No intermediate sizes in the 15 to $45 \AA$ range (that is, between opal and chert cristobalite) have been observed.

Tangential welding of siliceous skeletons (Figure 1) is common, particularly in the deeper samples from carbonate-rich sections. This probably results from compaction due to overburden pressure. As skeletons are forced into contact, pressure solution and cementation occur at the contact points. This welding is not accompanied by any apparent change in mineralogy, and does not appear to be a necessary precursor to chert formation. Although cherts containing identifiable siliceous skeletons are common, it appears that most of the opaline silica passes through a solution step before becoming chert.

\section{PELAGIC CLAY}

None of the Leg 7 sites is located in an area of modern "classic" pelagic clay. Site 61 may have drilled through fine-grained volcanogenic material, but the Cenozoic section was not cored. The Quaternary sediment at Site 63 is pelagic clay containing considerable numbers of calcareous and siliceous microfossils. In addition to the biogenous particles, the sand-size fraction contains volcanic glass and numerous micronodules. The silt and sand size components are rich in both terrigenous (quartz, chlorite, illite) and volcanic (plagioclase, pyroxene, montmorillonite) components, as might be expected from the location of the site. This sediment grades down to calcareous ooze. The low carbonate content of the surface sediment apparently results from a late Cenozoic rise in the calcite compensation depth (Heath 1969a), perhaps supplemented by depression of the sea floor, rather than from a radical change in the rate of nonbiogenous deposition.

The most striking pelagic clay sampled on Leg 7 was encountered in Hole 66.0. From about 162 to 192 meters, this hole intersected very stiff, light brown intensely mottled clay. This unit corresponds to a lower acoustically transparent layer on the reflection seismic records. The clay is extremely fine-grained, with no sand-sized fraction, and up to 93 per cent by weight finer than 2 microns. Its textural and mineralogical characteristics have some affinities with those of the early Tertiary clay sampled at Site 12 on Leg 2 (Peterson et al., 1969). The silt-sized fraction of the sediment contains quartz, anorthoclase and poorly crystallized illite, with minor plagioclase, pyroxene, palygorskite and chlorite. The clay-size contains abundant palygorskite in the upper part of the section, together with montmorillonite which dominates the lower part.

Paleo-latitude determinations on central Pacific seamounts (Francheteau et al., 1968) and the displacement 


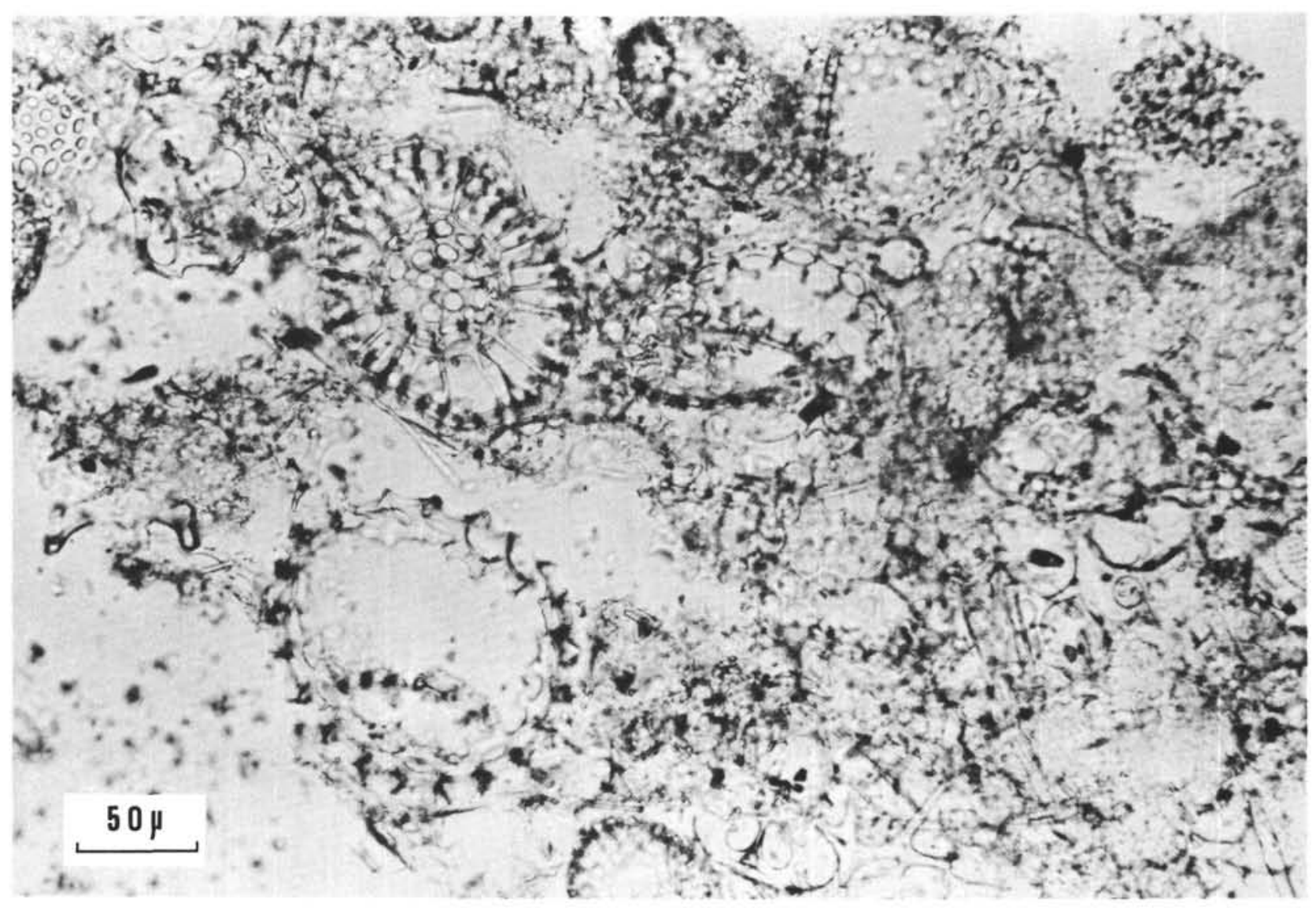

Figure 1. Meshwork of tangentially welded siliceous tests left after dissolution of calcareous matrix by $1 N$ hydrochloric acid. The meshwork retains the shape of the original chalk fragment. Bar is 50 microns long, plane polarized light, and sample designation is 7-64-0-8-1, 0-2 cm.

of the Pacific lithospheric plate deduced from magnetic anomalies parallel to the East Pacific Rise (Heirtzler et al., 1968) suggest that 60 million years ago, Site 66 lay south of the equatorial zone of high productivity at a latitude of about $135^{\circ} \mathrm{W}$. The clay section represents a period of 20 to 30 million years. For steady sedimentation, this gives an accumulation rate of 1 to $1.5 \mathrm{~m} / \mathrm{m} . \mathrm{y}$. (perhaps 2 to $3 \mathrm{~m} / \mathrm{m} . \mathrm{y}$. for uncompacted material). This rate is several times greater than that measured for modern South Pacific deposits (Goldberg and Koide, 1962), but is similar to modern rates in the central North Pacific (Ku et al., 1968) where eolian continental debris dominates nonbiogenous sedimentation. Although the presence of angular quartz shards in the Site 66 clay implies a continental source, the fine size of the sediment, the absence of bedding, the location of the site (approximately $135^{\circ} \mathrm{W}$ at the beginning of the Tertiary, and presumably separated from the continent by a mid-ocean ridge), and the occurrence of ferromanganese concretions throughout the section suggest that episodic or turbidite-type deposition was not important. Either eolian or nepheloid-layer transport appears capable of introducing terrigenous debris at the rate calculated (Windom, 1969; Heezen et al.,
1966). The latter is the more likely mechanism, since the grain-size distribution at Site 66 is unlike modern eolian samples.

The occurrence of abundant palygorskite above montmorillonite-rich clay suggests that the magnesiumbearing solutions responsible for the formation of the palygorskite moved laterally to Site 66 , rather than originating from the basaltic basement cored at the site. The abundant volcanic debris in the Site 66 clay, together with the palygorskite and ferromanganeserich intervals, are perhaps indicative of the intense volcanic activity in the vicinity of a mid-ocean ridge crest (Bostrom et al., 1969). On the other hand, the lack of calcareous organisms throughout the section suggests that Site 66 did not originate on a topographic high comparable to the modern East Pacific Rise.

The appearance of highly silieeous sediments in the middle Eocene at Sites 65 and 66 suggests that the sites crossed from an unproductive central water mass to the equatorial zone of high biological productivity at that time. 


\section{ASSOCIATED COMPONENTS}

\section{Fish debris}

All the noncalcareous deposits contain sand-sized phosphatic fish debris. This material forms as little as a fraction of a percentage of the $>63$ micron particles in pure siliceous ooze, or as much as 90 per cent of the same size fraction in the finest pelagic clay. Occasional teeth can be recognized, but most particles are irregular in shape with typical undulatory extinction. X-ray diffraction analysis of this material shows only poorly crystalline carbonate fluorapatite. The crystallinity and composition of the phosphorite, in as much as they affect X-ray diffraction patterns, appear to be independent of age.

The presence of abundant fish debris in ancient, as well as modern, pelagic deposits apparently indicates only a slow rate of accumulation of sediment. The present reconnaissance investigation is not quantitative enough to detect changes in the rate of phosphate deposition through the Cenozoic, even if they exist.

\section{Ferromanganese Concretions}

Both the siliceous oozes and nonfossiliferous pelagic clays contain micronodules and nodules of ferromanganese oxides and hydroxyoxides. The preservation of such nodules is strong evidence that conditions in the enclosing sediment have always been oxidizing (in contrast to the reducing conditions which led to the formation of pyrite concretions in the calcareous oozes). The high permeability of the siliceous oozes probably allowed sufficient oxygen to diffuse into the sediment to oxidize all reactive organic matter. In the pelagic clay, on the other hand, the amount of oxidizable organic matter incorporated into the sediment was probably too small to exhaust the available oxygen.

\section{REFERENCES}

Bostrom, K., Peterson, M. N. A., Joensuu, O. and Fisher, D. E., 1969. Aluminum-poor ferromanganoan sediments on active oceanic ridges. J. Geophys. Res. 74 (12), 3261.

Francheteau, J., Sclater, J. G., Richards, M. L. and Harrison, C. G. A., 1968. Comments on paper by
G. R. Schimke and C. G. Bufe: Geophysical description of a Pacific Ocean seamount. J. Geophys. Res. 73 (24), 7713.

Goldberg, E. D. and Koide, M., 1962. Geochronological studies of deep-sea sediments by the ionium/thorium method. Geochim. Cosmochim. Acta. 26, 417.

Heath, G. R., 1968. Mineralogy of Cenozoic deep-sea sediments from the equatorial Pacific Ocean. (Ph.D. dissertation; Univ. Calif. San Diego, Scripps Institution of Oceanography,) $168 \mathrm{pp}$.

Heath, G. R., 1969a. Carbonate sedimentation in the abyssal equatorial Pacific during the past 50 million years. Bull. Geol. Soc. Am. 80, 689.

Heath, G. R., 1969b. Mineralogy of Cenozoic deep-sea sediments from the equatorial Pacific Ocean. Bull. Geol. Soc. Am. 80, 1997.

Heezen, B. C., Hollister, C. D. and Ruddiman, W. F., 1966. Shaping of the continental rise by deep geostrophic contour currents. Science. 152, 502.

Heirtzler, J. R., Dickson, G. O., Herron, E. M., Pitman, III, W. C. and Le Pichon, X., 1968. Marine magnetic anomalies, geomagnetic field reversals, and motions of the ocean floor and continents. J. Geophys. Res. $73(6), 2119$.

Krauskopf, K. B., 1959. The geochemistry of silica in sedimentary environments. Soc. Econ. Paleontol. Mineral. Spec. Publ. (7), 4.

Ku, T. -L., Broecker, W. S. and Opdyke, N., 1968. Comparison of sedimentation rates measured by paleomagnetic and the ionium methods of age determination. Earth Planet. Sci. Letters. 4, 1.

Moore, T. C., Jr., 1969. Radiolaria: change in skeletal weight and resistance to solution. Bull. Geol. Soc. Am. 80, 2103.

Peterson, M. N. A., Edgar, N. T., von der Borch, C., Cita, M. B., Gartner, S., Goll, R. and Nigrini, C., 1970. Site 12. In Peterson, M. N. A. et al., 1970, Initial Reports of the Deep Sea Drilling Project, Volume II. Washington (U. S. Government Printing Office) 249.

Rex, R. W., 1958. Quartz in sediments of the central and North Pacific basin. (Ph.D. dissertation; Univ. Calif. Los Angeles, Scripps Institution of Oceanography.) $110 \mathrm{pp}$.

Windom, H. L., 1969. Atmospheric dust records in permanent snowfields: implications to marine sedimentation. Bull. Geol. Soc. Am. 80, 761. 